\title{
Introduction: The Politics of Leisure
}

\author{
Anna Clark
}

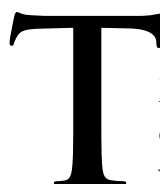

his issue focuses on the politics of leisure, a theme that serendipitously emerged from submissions to the journal. All the articles in this issue were submitted through the usual process. They bring to life the lively leisure activities of British society with vivid details and acute analysis.

The historiography of leisure has moved far beyond the old thesis of social control, the idea that the bourgeoisie or government manipulated leisure provisions for the working class to ensure their acquiescence and submission to the established order. Now, historians analyze leisure activities as a process of complex negotiations between authorities, reformers, leisure entrepreneurs, and audiences. ${ }^{1}$

During the eighteenth century, commercialized leisure for the middle class and elite expanded dramatically as part of the burgeoning urban culture. ${ }^{2}$ By the first decades of the nineteenth century, moral reformers cracked down on popular amusements, but, in "Vauxhall Revisited: The Afterlife of a London Pleasure Garden, 1770-1859," Jonathan Conlin demonstrates that they did not always succeed in closing down such venues. He traces the Vauxhall Gardens, a London pleasure ground, from its eighteenth-century heyday to its nineteenth-century re-creation and final decline. Interestingly, he identifies "autovoyeurism," the practice of going to the gardens to see and be seen, as a particularly eighteenth-century experience. To adjust to the new realities of the nineteenth century, Vauxhall entrepreneurs had to introduce more spectacular entertainments that would appeal to families, changing this dynamic. Despite the strictures of reformers, Londoners remembered the old Vauxhall of their youth as they attended the new, with a keen sense of nostalgia that gave a bittersweet pleasure to their leisure.

Poses plastiques, or tableaux vivants, which recreated famous paintings, events, or statuary with motionless actors, appeared at Vauxhall in 1837, having first been introduced publicly in London in 1829. Predictably, late nineteenth-century moral reformers claimed that these female performers, clad in nude body stockings, were indecent. But as Brenda Assael's article, "Art or Indecency? Tableaux Vivants on the London Stage and the Failure of Late Victorian Moral Reform," demonstrates, their demand to close down these performances was not granted. Some municipal

\footnotetext{
${ }^{1}$ Peter Bailey, "The Politics and Poetics of Modern British Leisure," Rethinking History 3, no. 2 (1999): 131-75.

${ }^{2}$ Marius Kwint, "The Legitimization of the Circus in Late Georgian England," Past and Present, no. 174 (February 2002): 72-115.
} 
authorities, and enthusiastic audiences, defended the tableaux vivants as artistic and aesthetic.

The next two articles of the issue explore the question of elite masculinity and leisure. They continue the theme of masculinity from the April 2005 special issue of $J B S$ (vol. 44, no. 2). Although masculinity is usually associated with the public sphere, both of these articles demonstrate that elite male bonding also occurred in private settings, which were seen as sanctuaries in which men could engage in leisure activities ranging from arcane scholarship and quiet dinners to bawdy romps and heavy drinking. These elite private masculinities had a contested relationship with both the public sphere and the private domestic world.

In "Riots, Revelries, and Rumor: Libertinism and Masculine Association in Enlightenment London," Jason Kelly writes about two incidents in which members of the Society of Dilettanti became embroiled in public controversies. Picking up on the continuing debate about whether the eighteenth century saw a shift from polite association to masculine libertinism, Kelly asserts that masculine libertinism continued, although the increased focus on politeness made it controversial. Gentlemanly libertines often faced the judgment of public opinion, whether in the form of mobs on the street, letters circulating among gentlemen, or the press. First, in $1734 / 5$, when some of the society's members held a feast on the anniversary of the execution of Charles I, a crowd on the street accused them of celebrating regicide, but these men preferred to defend themselves through private gossip and rumor, and in letters, rather than making a counterattack in the press. In contrast, in 1763, John Wilkes deliberately publicized the wild goings-on at Medmenham Abbey, the erotic playground of Society of Dilenttanti member Sir Francis Dashwood, as a weapon in his political struggles. This demonstrates a shift in the public and private deployment of rumor and gossip about masculine reputations.

Amy Milne-Smith's article, "A Flight to Domesticity? Making a Home in the Gentlemen's Clubs of London, 1880-1914," is replete with interesting information about the clubs, with their ornate, plush dining rooms filled with the low murmur of masculine conversation, the lounges with their crackling fires and rustle of newspapers, and officious doormen keeping out importuning creditors-and wives. The clubs were truly a sanctuary, and a home away from home, and MilneSmith ingeniously argues that they provided a form of domesticity-including delicious food, lodging, friendship, and belonging — as an alternative to the middleclass home, where they might face the emotional demands of fatherhood and marriage. Men could combine business and leisure, in a public space that also allowed the privilege of privacy.

We conclude with two articles on film in the era of World War II Britain. The cultural politics of the Second World War are clearly an arena of keen historiographical interest, as evidenced by the two articles on photography in the January 2006 issue of $J B S .{ }^{3}$ Our current articles, Jo Fox's "Millions Like Us? Accented Language and the 'Ordinary' in British Films of the Second World War" and Carolyn Levine's "Propaganda for Democracy: The Curious Case of Love on the

\footnotetext{
${ }^{3}$ Martin Francis, "Cecil Beaton's Romantic Toryism and the Symbolic Economy of Wartime Britain," Journal of British Studies 45, no. 1 (2006): 90-117; and Steven Brooke, "War and the Nude: The Photography of Bill Brandt in the 1940s," Journal of British Studies 45, no. 1 (2006): 118-38.
} 
Dole," nicely complement each other in addressing the question of cinematic propaganda. The British government needed to enlist film in the service of wartime propaganda but faced several problems in doing so. First, they did not want to seem like the Germans; their propaganda had to seem more honest and subtle. Second, the idea of the People's War was that Britons were fighting for a better world, not a return to the old class divisions and poverty of the interwar period. British film actors tended to use upper-class accents and depict an upper-class world, alienating to working-class audiences, who often preferred American films for their perceived classlessness, as Fox observes.

Furthermore, before the war the British film censors prohibited not only sexual themes in film but also any allusion to class conflict or strikes. For instance, they refused to allow Walter Greenwood's gritty novel Love on the Dole to be made into a film. But during the war, Levine has discovered, officials apparently encouraged filmmakers to turn it into a movie, which showed the British public that the government was willing to be more honest about social conditions than were German propagandists.

Fox demonstrates how the government-urged on by documentary filmmakers-urged directors to appeal to a large audience in propaganda films by using a broader range of actors - or even real people - who spoke with regional or working-class accents. Filmmakers such as Noel Coward, in his In Which We Serve, incorporated stories about ordinary people into a compelling fictional narrative of heroic sacrifice.

Due to the special theme of this issue, there are no articles on medieval or early modern Britain, but we featured a special section in the April 2006 issue with three early modern articles, and future issues will continue to include articles on the earlier periods. 